\title{
Polymeric Biomaterials with Complementary Role in the Articular Endoprosthesis \\ I. Surface Characteristics
}

\author{
DANA NICOLETA MIHAI ${ }^{1,2}$, DAN MIHAILESCU ${ }^{3,2 *}$, SORIN ALEXANDRU IBANESCU4, LILIANA SAVIN ${ }^{3,2 *}$, VICTOR GRIGORESCU ${ }^{3,2}$, \\ ALEXANDRU PATRASCU ${ }^{5}$, MARCEL IONEL POPA ${ }^{1}$ \\ ${ }^{1}$ Gheorghe Asachi Technical University of Iasi, Cristofor Simionescu Faculty of Chemical Engineering and Environmental \\ Protection, 73 Dimitrie Mangeron Str., 700050, Iasi, Romania \\ ${ }^{2}$ Clinical Rehabilitation Hospital, Orthopaedic Trauma Surgery Clinic, 14 Pantelimon Halipa Str., 700661, Iasi, Romania \\ ${ }^{3}$ Grigore T. Popa University of Medicine and Pharmacy, 16 Universitatii Str., 700115, Iasi, Romania \\ 4.Petru Poni Institute of Macromolecular Chemistry lasi, 41A Grigore Ghica Voda Alley, 700487, Iasi, Romania \\ ${ }^{5}$ Sf.Dimitrie City Hospital, 35 Stefan cel Mare Str., 610109, Targu Neamt, Romania
}

\begin{abstract}
The change of the organic bone cements'composition (COO) determines the adjustment of some important properties for the behaviour as fixing material, such as the: superficial tension, polarity, surface energy, viscosity, contraction at polymerisation, porosity. In the present paper we monitored the influence of the composition's changes for some acrylic cements upon their handling features. The samples were obtained via the partial replacement of the methyl methacrylate (MMA) in the liquid phase of some usual formulas with another acrylic monomer. For these, it was measured the contact angles as wettablility of the fixing material. Moreover, it was estimated the values of the hardening time, important parameter for the application phases of the cements with cold hardening and fixing of the articular endoprostheses.
\end{abstract}

Keywords: Organic bone cements, acrylic copolymers, contact angle, hardening time

In the last decades, the orthopaedic surgery registered a spectacular evolution following the improvement of the prosthetic devices' features, of the applied surgical techniques, butespecially of the progress in the polymeric biomaterials field [1-5]. The composite biomaterials used in the endoprosthetic interventions are highly useful due to some properties such as the exceptional resistance in connection to their specific weight or their superior biocompatibility [6].

In addition to the physical and chemical special properties, the polymeric materials show also an important feature and namely the possibility to project their features such that they answer as much as possible to the requirements imposed by such a usage [7,8].

The diversity of the composite biomaterials of the orthopaedic usage, but especially the specificity of their physical and chemical features allows for their grouping according to the role which they possess in the recreation of an articulation $[9,10]$.

Thus, the polymeric compositions of orthopaedic usage can be grouped in:

-Non-biodegradable (reconstruction) materials

-Bioresorbable composite (most often for tissue are used for the replacement of ligaments or tendons, as well as for bone reconstructions [6].

The articular reconstructions imply, in addition to using prosthetic devices, the usage of materials whose role, although complementary, is very important for the successful intervention. The biocomposites in this group are materials for fixing the prostheses, like the organic bone cement (COO) type. Among these, the acrylic cements with hardening at room temperature hold a top position due to the simplicity of application, of the good post-surgery results in the short and average term, of the good morphological adaptation and of the possibility to transfer the efforts in the prosthese/bone assembly.

\section{Experimental part}

The analysed cements were obtained via the partial replacement of the classic monomer (MMA) in the liquid phase with another acrylate, butyl acrylate (BuA). The materials were prepared according to the experimental protocol shown above [11]. The three CCO series have the compositions mentioned in table 1 .

The watering (contact) angle was established via the dripping-method deposited on a horizontal surface. It was replacement)

\begin{tabular}{|c|c|c|}
\hline \multirow{2}{*}{$\begin{array}{l}\text { Cement } \\
\text { sample }\end{array}$} & Solid phase & Liquid phase \\
\hline & PMMA/P(MMA-c0-\$) proportion & MMA/BuA (v/v) proportion \\
\hline $\mathrm{CCl}$ & \multirow[b]{3}{*}[\mathrm{PMMA}]{$=100 \% ;[\mathrm{P}(\mathrm{MMA}-\mathrm{co-S})]=0 \%$} & $1 / 0$ \\
\hline $\mathrm{CC} 2$ & & $1 / 1$ \\
\hline $\mathrm{CC} 3$ & & $1 / 4$ \\
\hline CP1 & \multirow{3}{*}{$\begin{array}{c}1 / 0,3 \\
{[\mathrm{PMMA}]=76 \% ;[\mathrm{P}(\mathrm{MMA}-\mathrm{co}-\mathrm{S})]=24 \%}\end{array}$} & $1 / 0$ \\
\hline $\mathrm{CP2}$ & & $1 / 1$ \\
\hline CP3 & & $1 / 4$ \\
\hline CS1 & \multirow{3}{*}{$\begin{array}{c}1 / \mathbf{5} \\
[\mathrm{PMMA}]=16 \% ; \mathrm{P}(\mathrm{MMA}-\mathrm{co}-\mathrm{S})]=84 \%\end{array}$} & $1 / 0$ \\
\hline CS2 & & $1 / 1$ \\
\hline $\operatorname{CS3}$ & & $1 / 4$ \\
\hline
\end{tabular}

Table 1

COMPOSITION OF THE PREPARED ACRYLIC CEMENTS

PMMA = poly(methyl methacrylate), $P(M M A-c o-S)=$ poly(methyl methacrylate-co-styrene),

MMA =methyl methacrylate, BuA=butyl acrylate

*email:danmih_86@yahoo.com, lilisavin@yahoo.com 


\begin{tabular}{|c|c|c|c|c|c|}
\hline \multirow{2}{*}{ CCO sample } & $\theta\left({ }^{\circ}\right)$ & \multirow{2}{*}{ CCO sample } & $\theta\left({ }^{\circ}\right)$ & \multirow{2}{*}{ CCO sample } & $\theta\left({ }^{\circ}\right)$ \\
\cline { 2 - 2 } & Water $/ \mathrm{EG}$ & & Water $/ \mathrm{EG}$ & & Water $/$ EG \\
\hline CC1 & $83.00 / 58.33$ & CP1 & $78.63 / 61.03$ & CS1 & $76.40 / 66.83$ \\
\hline CC2 & $83.43 / 70.00$ & CP2 & $90.58 / 66.61$ & CS2 & $53.70 / 54.43$ \\
\hline CC3 & $92.40 / 81.39$ & CP3 & $83.00 / 50.07$ & CS3 & $91.58 / 71.30$ \\
\hline
\end{tabular}

Table 2

WATER AND ETHYLENE GLYCOL WETTING ANGLES $(\theta)$ used the KRUSSEasy Drop Standard goniometer, endowed with the automatic system for capturing and analysing the geometry of the drop (video camera and DSA 1 software). On the surface of the freshly prepared cement sample, two liquids with different polarity were deposited, water and glycol ethylene (EG) [12].

In order to estimate the hardening time, a qualitative method was applied. The cement samples were deposited on a glass support and it was monitored the evolution in time of the footprint of the spherical head of the Hoppler consistometer (diameter $\Phi=16 \mathrm{~mm}$ ), the loading of the pole being equal for all the recordings.

\section{Results and discussions}

The change of the composition determines also the adjustment of some important properties for the behaviour as fixing material, such as the: superficial tension, polarity, surface energy, viscosity, contraction at polimerisation, porosity $[7,8,13,14]$.

The values of the static wetting angles (fig. 1) corresponding to the studied composites are summarized in table 2 [15].

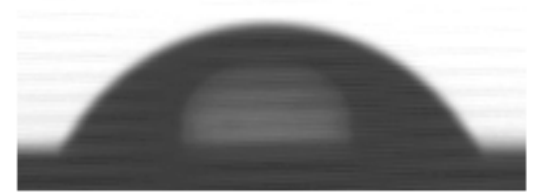

Fig. 1 Image of the water drop deposited on CS2 sample - cement with lowest contact angle

It can be seen that, in the $C C$ series, the wetting angle decreases at the same time with the increase of the butyl acrylate content, thus obtaining the order $\mathbf{C C 1}<\mathbf{C C 2}<$ CC3. The increase of the wetting angle for the samples with high content in the BuA units may be due to the increase of the cohesion between the polymeric links. The BuA units act as a compatibilization agent between the matrixpolymer (the PMMA in the solid phase of the cement) and the polymer formed in the preparation stage of the $\mathrm{CCO}$ through the polimerisation of the comonomers included in the liquid phase of the cement.

As it was expected, the presence and the proportion of the non-polar styrene units in the solid phase of the cement formula changes the balance between the adhesion and cohesion forces. This influence, to which it is added also that induced by the concentration of the Bu units, leads to the following order of the cements' wetness:

\section{$\mathrm{CP} 1<\mathrm{CP} 3<\mathrm{CP} 2 ; \mathrm{CS} 2<\mathrm{CS} 1<\mathrm{CS} 3$}

No matter the composition, the processes which occur during cement preparation shows that after bringing into contact the two components of the cement, it starts the swelling of the polymer particles in the added monomer. The swelling process is accompanied by the start of the matrix polymerization reaction. The mixture, continuously homogenized in order to favour the freeing of the reaction heat, reaches the non-adhesive plastic state. After this stage, the material is introduced in the medullary canal where the polymerization is finalized and the cement becomes solid, hard and compact (fig. 2) [16].

The hardening time, parameter determining the handling features for the acrylic orthopaedic cements, is strongly influenced by the nature and ratio of the components $[7,13,14]$. A reduced handling timing (the plastisol phase) could increase the probability of the loss of the ideal moment for the application of the cement [13].

The evolution in time of the footprint left on the cement's surface by a metallic ball upon the application of a constant force can supply useful information with regard to the evolution of the cement hardening process (fig. 3).

The results regarding the hardening time shows that its value is influenced by the composition of the cement, being obtained for the samples of the three series the following order:

$$
\mathrm{CC} 1<\mathrm{CC} 2<\mathrm{CC} 3 ; \mathrm{CP} 1<<\mathrm{CP} 2<\mathrm{CP} 3 ; \mathrm{CS} 1<\mathrm{CS} 2<\mathrm{CS} 3
$$

For the samples in various series, but with equal content of BuA, the hardening time is ordered thus: $\mathbf{C C}<\mathbf{C P}<<$ CS

The information obtained, even if it has only a qualitative order, shows that the partial replacement of the MMA with BuA leads to the increase of the polimerisation duration,
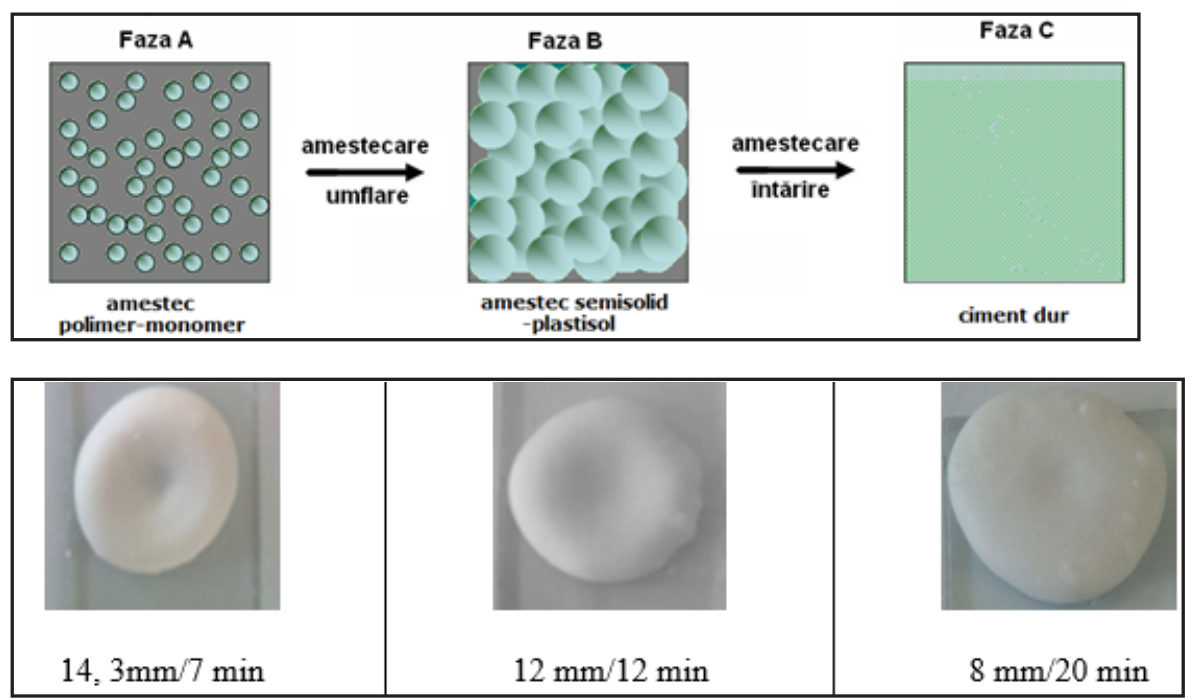

Fig. 2 Stages of the preparation process for an acrylic cementing material

Fig. 3 Evolution of the foot print of the HOPLER consistometer's ballon the cement sample $\mathrm{CC} 1$ 
namely to the increase of the cement hardening time. This can be due because of the fact that, in the same reaction conditions, the BuA presents a slower polimerisation speed than the MMA $\left(\mathrm{k}_{\mathrm{p}(\mathrm{MMA})}=573 \mathrm{l} / \mathrm{mol} \mathrm{s}, \mathrm{k}_{\mathrm{p}(\mathrm{BUA})}=14,5 \mathrm{l} / \mathrm{mol} \mathrm{s}\right)$ $[15,17]$.

\section{Conclusions}

The value of the contact angle both in connection to the water, as well as with the ethylene glycol changes at the same time with the composition of the cement because of the different polarity between the MMA and the BuA units.

The partial replacement of the MMA units with 5 - $20 \%$ BuA units increases the cement hardening timing, allowing for the extension of the drafting and application time of the fixation material for the articular prosthesis.

\section{References}

1.YUFEI TANG, LEI CHEN, ZIXIANG WU, KANG ZHAO, QUANCHANG TAN, Comp. Sci. Techn., 146, 2017, p. 203

2. CARAAN, N. A., W INDHAGER, R., WEBB, J ., ZENTGRAF, N., KUEHN, K. D., World. J. Orthop., 8, nr. 12, 2017, p. 881

3.SCHOLZ, M. -S., BLANCHFIELDS, J. P., BLOOM, L. D., COBURN, B. H., ELKINGTON, M., FULLER, J. D., GILBERT, M. E., MUFLAHI, S. A., PERNICE, M. F., RAE, S. I., TREVARTHEN, J. A., WHITE, S. C., WEAVE, P. M., BOND I. P., Comp. Sci. Techn., 71, nr. 16, 2011, p. 1791

4.WEBB, J. C., SPENCER, R. F., J. Bone J oint Surg. (Br), 89, nr. 7, 2007, p. 851
5.KUEHN, K. D, EGE W., OrthopClin North Am., 36, 2005, p. 17 6.RAMAKRISHNA, S., MAYER, J., WINTERMANTEL, E., LEONG KAM W., Comp. Sci. Techn., 61, nr. 9, 2001, p. 1189

7.SANTOS J r., J. G. F., PITA, V. J . R. R., MELO1, P. A., NELE, M., PINTO, J. C., , Braz. J. Chem. Eng., 28, nr. 2, 2011, p. 229

8.GONCALVES, P. P., SINNGH, M. K., SILVA, V. S., MARQUES, F., MARQUES, A., LeDUC, P. R., MARQUES, P. A. A. P., GONCALVES, G., SOUSA, A. C. M., Pure Appl. Chem., 83, nr. 11, 2011, p. 2063

9.RUSU, M. C., IBANESCU, C., ICHIM, I. C., RIESS, G., POPA, M., RUSU, D., RUSU, M., J. Appl. Polym. Sci., 111, 2009, p. 2493

10.WEI W., ABDULLAYEVE., HOLLISTE A. M., MILLS D. K., LVOV Y, Macromol. Mat. Eng., 297, nr. 7, 2012, p. 645

11.MIHAILESCU, D., DANU, M., SIMIONESCU, B., BOTEZ, P., SAVIN, L., IBANESCU, S. A., Mat. Plast., 54, no. 3, 2017, p. 567

12.AZIZIAN S., HEMMATI M., J. Chem. Eng. Data, 48, nr. 3, 200, p. 662 13.RUSU, M. C., RUSU, D. L., RUSU, M., ICHIM, I. C., J. Optoelectron. Adv. M., 12, nr. 2, 2010, p. 339

14.LAI P. L, CHEN L. H., CHEN W. J., Chu I. M., Biomed. J., 36, nr. 4, 2013, p. 162

15.MIHAILESCU, D., 2015, Revision hip arthroplasty, Ph. D. diss., University of Medicine and Pharmacy Grigore T. Popa Iasi 16.MIHAILESCU D., DOROFTEI F., PELIN I. M., MIHAILESCU C., BOTEZ P., Colloque Franco-Roumainsur les Polymeres, Pitesti, 27-29 aot, 2014, Actes du Coloques., 1, 2014, p. 102.

17.*** Polymer data handbook, Mark J. E. Ed., 2nd Ed. 2009, Oxford University Press Inc e-ISBN 978-1-61583-061-9, http://www. toarplast. co. il/linksPage/HandBook. pdf

$\overline{\text { Manuscript received: } 19.03 .2019}$ 